\title{
Listening to Intergalactic Sounds - Articulation of Rastafarian Livity in Finnish Roots Reggae Sound System Performances
}

\author{
TUOMAS JÄRVENPÄÄ \\ University of Eastern Finland
}

\begin{abstract}
:
Rastafari is an Afro-Jamaican religious and social movement, which has since the 1970s spread outside of the Caribbean mainly through reggae music. This paper contributes to the academic discussion on the localization processes of Rastafari and reggae with an ethnographic account from the Nordic context, asking how Finnish reggae artists with Rastafarian conviction mobilize this identification in their performance. The paper focuses on one prominent Finnish reggae sound system group, Intergalaktik Sound.

The author sees reggae in Finland as divided between contemporary musical innovation and the preservation of musical tradition. In this field, Intergalaktik Sound attempts to preserve what they consider to be the traditional Jamaican form of reggae sound system performance. For the Intergalaktik Sound vocalists, this specific form of performance becomes an enchanted space within a secular Finnish society, where otherwise marginal Rastafarian convictions can be acted out in public. The author connects the aesthetic of this performance to the Jamaican dub-music tradition, and to the concept of a 'natural life', which is a central spiritual concept for many Finnish Rastafarians. The article concludes that these sound system performances constitute a polycentric site where events can be experienced and articulated simultaneously as religious and secular by different individuals in the same space.
\end{abstract}

Keywords: Rastafari, sound system, localization, re-enchantment, ethnography

Reggae, in its various forms, has emerged during the past decade as one of the most visible and vibrant forms of Finnish popular music. This Jamaican popular music form is in Finland in a process of increasing diversification, where it is articulated to different fields of cultural production. Thus the sounds and practices of reggae are potential terrains for cultural anxieties and shifting re-articulations of localities and identities. In this paper, 
I approach Finnish reggae as a scene which, following Will Straw's (1991) conceptualization, I see as a cultural space situated in a specific geographical location and where a range of musical practices coexist with and influence each other. As Straw continues, scenes are often divided between the preservation of musical tradition and contemporary innovation. This dynamic is very present at the moment in Finnish reggae, as Kim Ramstedt (2014) has recently observed. A number of bands and artists, such as Jukka Poika or Reino Nordin, have articulated the sound of reggae with the lyrical and musical conventions of Finnish pop music, thus creating a new musical genre named suomireggae - 'Finnish reggae music'. Alongside with these local reggae artists, contemporary Jamaican dance music, or dancehall music, is enjoying unprecedented status in urban Finnish clubs. In contrast to these developments, a number of reggae aficionados are at the same time increasingly concerned over preserving what they consider as traditional reggae music, or roots reggae, which they see as integrally linked to the Rastafari Afro-Caribbean political and religious movement.

My research question in this ethnographically grounded article is to ask how Finnish vocal artists identifying themselves as Rastafarians construct this notion of roots reggae in live club performances. I analyze especially the ways how they identify to the Rastafarian movement with the specific use of sound and performance techniques. Religious themes derived from the Rastafarian movement have been instrumental in reggae music since its breakthrough on the world music markets in the 1970s. The relationship between Rastafari and reggae, and the localizations of Rastafari outside of Jamaica, have since then been subject to intense academic attention (see for example Hebdige 1979, 30-45; Cashmore 1982; Savihinsky 1994; Gilroy 1995, 153-222; Van Dijk 1998; Rommen 2006; Sterling 2010; ̈̈ystö 2012). This article contributes to this theoretical discussion by offering a perspective on the localizations of Rastafarian identities in popular music performances in the Finnish context.

The Rastafarian movement emerged in the 1930s among the black population of Jamaica as a part of a tradition of cultural resistance to the colonial order. Central in the movement is the belief in the divinity of the late Ethiopian Emperor, Haile Selassie. By this creed, the movement has celebrated black identities, which were formerly neglected in the Jamaican national consciousness. (Chevannes 1994.)

The Rastafarian movement in Finland has thus far received little scholarly attention. The community of Rastafarians in Finland is small, consisting of around a few hundred individuals without formal organizational structures. In his empirically grounded master's thesis, Tuomas Äystö (2012) 
observed that Rastafarians from a Finnish background hold a great variety of beliefs, many of which have been localized from their Caribbean origins to the Finnish cultural milieu. For example, the sage Väinämöinen, from the Finnish national epic Kalevala, is seen among some (though not all) Finnish Rastafarians as a source of spiritual inspiration. The unifying factor between Rastafarian individuals both in Finland and globally is the adherence to a set of practices known as livity, which includes for example a set of dietary regulations and often the use of dreadlocks. In the Caribbean context, the use of specific language derived from English, known as dread talk, has been central to livity (Pollard 2000; Homiak 1995). Äystö concludes that through the concept of livity the Finnish Rastafarian movement is able to sustain a great diversity of individual beliefs. Rastafarians see livity as a natural and ecological way of life and as ideal of material self-sustainability. Among Finnish Rastafarians this connection to nature is often seen as the essence of the movement. These views on a natural life bear a resemblance to broader countercultural currents in the West, and also resonate with older European occult traditions. (Äystö 2012.)

In addition to theorizing the localizations of Rastafari, this case study offers an empirical contribution from a Nordic context to the growing discussion in the comparative study of religion on the re-enchantment of popular culture in the Western world. Re-enchantment has been seen as a process where popular culture and consumer commodities become sources for spiritual practices, in ways which do not channel into existing religious movements. The concept has been discussed by a number of scholars, but so far only a few detailed ethnographic contributions have addressed the actual social dynamics of this process in the context of popular music (Partridge 2004; Lynch 2006).

\section{Musical Codes in Superdiverse Settings}

Analytically, my paper is based on the seminal work of Mark Slobin (1993), Subcultural Sounds: Micromusics of the West. In this publication Slobin sketches a model to understand the agency of musical performers in different contexts. In his words, this aim is to comprehend 'small musics in big systems'. Thus he sees that artists negotiate their expression between different cultural fields. Slobin makes a distinction between close-knit musical units and forms of performance, which he terms 'subcultures', and mainstream cultural production or 'superculture', which is widely mediated both nationally and internationally. In addition, he identifies various 'intercultural' links, which mediate musical influence between different supercultural and subcultural musical 
units. For Slobin, these intercultural links are based on affinitive personal contacts, diasporic movement or industrial distribution. (Slobin 1993, 27-82.)

The crux in Slobin's study is the flow of music and performers between different cultural units or spheres. To understand this process he uses the sociolinguistic concept of 'code-switching', which he defines, referring to William Labov, as 'moving from one consistent set of co-occurring rules to another'. Slobin continues his definition by quoting Susan Gal's formulation: 'Code switching is a conventional strategy used to establish, cross or destroy group boundaries; to create, evoke or change interpersonal relations'. (Slobin 1993, 85. On musical code switches in Jamaican music traditions, see for example Stolzoff 2000, 22-31, 97-99.) In the context of music, Slobin applies these rules to musical style or the whole 'mix of repertoire and mode of presentation that we anticipate when we buy an album or go to a concert'. Musicians negotiate these codes and switch dynamically between them. As Slobin puts it, 'subcultural musicians keep one eye on their in-group audience and the other on the superculture, looking out for useful codes and successful strategies, while a third inner eye seeks personal aesthetic satisfaction'. (Slobin 1993, 27-82.)

In the field of reggae, I see this musical code switching in the context of the global cultural economy. Jan Blommaert (2010, 28-62) has recently analyzed sociolinguistic codes in relation to global cultural flows with special emphasis on inequality in language resources. He describes the current form of global economy with the term 'superdiversity', meaning that increased mobility and new technology have increased the number of indexical orders that individuals are expected to possess and combine. With indexical order, Blommaert refers to expressive forms which act as cultural indexes to specific social roles and identities. These resources are in a hierarchical relationship and tension with each other. Dread talk, for example, might be a valuable resource in the context of reggae clubs, but if the speaker does not possess other more suitable language resources, and uses this form of English in a tax office in Finland, it can be seen as merely a sign of incompetence. These patterns of authority and power emerge from real or imagined indexical centers, which have become increasingly polycentric in nature, with numerous indexical orders referring to different centers. In the field of reggae, Jamaican music scenes might be examples of such indexical centers.

On this diverse terrain, I will analyze what stylistic elements are brought together and named and treated as Rastafarian by the artists involved in reggae scenes. Here I will apply the concept of articulation as outlined by Stuart Hall (Slack 1996). The concept refers to the attempts to unite differ- 
ent and potentially disparate discursive elements. Articulations are not a product of conscious artistic or other individual activity, but are produced by a complex web of social and material relations.

The material of my analysis is based on ethnographic fieldwork, which I conducted mainly during 2012. During the year, I interviewed a number of Finnish reggae performers and organizers and conducted observations at reggae events in several cities. I documented these events with a field diary (Field diary 2011; Field diary 2012). I presented myself as a researcher in comparative religion, and thematically I focused on the religious aspects of reggae music in the interviews. Most of the research participants, however, did not see religion or spirituality as in any way a part of their musical activity. From this data, I have selected a group named Intergalaktik Sound as the ethnographic focus for this article. Unlike most of the research participants, the vocalists of this group describe themselves in the interview situations as Rastafarians by conviction. I follow how these performers are able to articulate their identity within the largely secular local reggae culture, even though as Rastafarians they are marginal both in this scene and in Finnish society at large. To contextualize the Intergalaktik Sound performances within the wider Finnish reggae culture, I will also use the interviews with two reggae promoters and organizers, who have been instrumental in forming the relevant performance sites for these vocalists.

\section{Finnish Sound System Reggae and Intergalaktik Sound}

In the reggae scenes of Britain and central Europe, there has historically been a strong diasporic influence, due to the migrations from the Caribbean (Hebdige 1979, 30-45; Cashmore 1982; Gilroy 1995, 153-222). In Finland, by contrast, because of the lack of large-scale Caribbean immigration, this music has until recently mainly been mediated by the music industries. The first fully-fledged local reggae bands and clubs emerged in the 1980s and 1990s. Kim Ramstedt (2014) has pointed out that the sound system performances and live ensembles of the emerging club culture fueled each other and together provided the conditions for a localized reggae culture in Finland. By the turn of the millennium, reggae ensembles and artists, mostly from a white middle-class background, and using Finnish language and localized themes, started to gain mainstream popularity.

In this paper, my interest is specifically in the dynamics of the sound system performances and practices, rather than instrumental ensembles. Traditionally the term 'sound system' refers to a group of artists, 'selec- 
tors', who function as disc jockeys, and to vocalists or 'DJs', who use the microphone to communicate with the audience or to rhyme and sing with recorded instrumental music tracks. Typically, sound system groups would own their own technological musical equipment, such as a public address system, amplifiers and a set of turntables with mixers. Besides executing an important sub-genre of reggae performance, the activities of these groups also set the central social practices for the reggae scenes. Currently, sound system groups or individual selectors are often responsible for organizing reggae events, producing records and generally introducing reggae music to local audiences in performances; in addition, they form a social network that offers platforms for local and foreign vocal artist and instrumental ensembles to tour and perform. (Stolzoff 2000, 113-50; Ramstedt 2014.)

Despite their identification as somewhat marginal roots reggae, Intergalaktik Sound has been one of the most prominent Finnish sound systems during the past few years, with several recent music releases and regular club nights. The group consists of the vocalists Nestori and Jahvice, and a number of selectors and more irregular members helping with the activities of the collective. Both vocalists, Nestori and Jahvice, already have a long history as amateur reggae musicians, and they have been involved in a number of reggae projects in the past. Nestori and Jahvice are Finnish males in their 30 s or 40 s, employed outside the music industry and with families of their own. In our interviews, they distinguished their group as roots reggae from the other sound system groups with three features.

The first feature, of which the members were particularly proud, was the fact that the group owns a set of fairly powerful speakers and amplifiers. Using this equipment, the group has organized a series of popular events during the summertime in recent years. Most of the other Finnish sound systems do not currently own their own equipment; instead they work mainly with public address systems that are provided by the performance venues or clubs. The members of Intergalaktik Sound have paid special attention to the sound of their group - specifically to the powerful bass. Because of this, there are only a few possible venues in Helsinki where group can actually play with their equipment. Typically, therefore, Nestori and Jahvice perform as solo artists in reggae events and indoor clubs that are hosted by other selectors or sound system crews. Even when performing individually, without the whole group or equipment, they are often advertised as members of the Intergalaktik label.

Secondly, since 2007, the group has released several reggae singles in vinyl format, featuring Nestori and Jahvice and a number of guest vocal- 
ists from outside Finland. This also distinguishes the group from most of the other Finnish sound systems, who have not produced vinyl releases. Currently, sound systems typically release their own mix tapes or specials in digital format, and distribute them via the Internet.

The final feature making the Intergalaktik Sound somewhat exceptional on the Finnish reggae scene is that the vocalists of the group link their music to the Rastafarian world-view and values. Both Nestori and Jahvice state that the Rastafarian movement has been spiritually significant for them personally throughout their adult life. I stress here again that a clear majority of the Finnish vocal artists and sound system groups are not Rastafarian by conviction, even though at the moment there are a few Rastafarian reggae groups besides Intergalaktik Sound.

This emphasis on maximum bass sounds, vinyl-format, and Rastafarian livity was all seen as part of their identification with roots reggae. For Jahvice and Nestori, this emphasis meant that they follow the tradition of Jamaican-derived sound system culture, rather than the contemporary currents of Jamaican music. In contrast, most Finnish sound systems and selectors track the new releases of Caribbean music very closely (on Finnish sound systems, see Ramstedt 2014). In our interview, Jahvice suggested that the traditional form of sound system performance is almost non-existent in Jamaica today, and is more alive in the sound system scenes of Britain and continental Europe. These European roots reggae sound systems form a transnational network of their own. (On European roots reggae sound systems, see Partridge 2010, 98-145; Veal 2007, 220-260.) To illustrate how these notions of authenticity and Rastafarian values are actually mobilized in performances in Finland, I will next describe two events where Intergalaktik Sound members were invited as guest performers. These descriptions are based on my written field notes, the music releases of the Intergalaktik label, and on the recorded formal interviews that I executed during the fieldwork.

\section{Secular Stomp? - Jahvice Performing in Reggae Stomp}

In the summer of 2012, when I first interviewed Jahvice in his studio, he told me that he would be throwing a show in the same night in a reggae club called 'Reggae Stomp' in Cafe Mascot in downtown Helsinki. He invited me to see the show, and thus I went to enjoy the club. Although the club was unfamiliar to me at the time, later I witnessed numerous reggae acts at this particular venue during the two months that I conducted observations and interviews in Helsinki. 
Active since the year 2009, Reggae Stomp was, and still is, a well-known weekly reggae club. During the summertime in 2012, the club was held every Wednesday and hosted by Andor, a male Finn in his early thirties, who was working at the time as a full time selector and a club promoter. Andor was particularly ambitious and well known in his craft, and seemingly had large social networks across Finnish and transnational reggae networks. Andor hosted several regular reggae-oriented clubs at the time. The concept of Reggae Stomp was to offer a low-cost venue to showcase reggae broadly by featuring different guest acts each week. Andor would kick off the nights by playing records and afterwards would be the time for guests to perform. After the performance, Andor would continue for the rest of the night with his selections. Most of the time these guests would be single vocalists like Jahvice, but full bands or individual selectors were also occasionally featured. Typically, the acts were Finnish performers, but foreign artists also visited Reggae Stomp from time to time.

During those two months when I visited Reggae Stomp regularly, it became apparent that Andor was trying to reach out with reggae music for the broadest possible audience. The crowd was young and diverse, partly due to the relatively low entrance fee and the central location of the venue. As a club held in the middle of the week, I observed that the venue was really full only when the more popular Finnish artists were performing. The most visible group in the audience seemed to be young Finnish women dressed for partying, but evidently more counter-culturally oriented white and black men and women, with their dreadlocks and tam caps, were also always present. Although the venue, Cafe Mascot, is classified as a cafeteria, the emphasis of Reggae Stomp seemed to be on dancing, on party-oriented reggae music, and on Finnish live performers.

Andor typically started his musical selections by playing mellower and older reggae tunes with relatively slow switches, but soon he would start playing the newest fast-paced contemporary music, constantly mixing from one tune to another. (On dancehall tunes and selecting techniques, see Stolzoff 2000, 193-247; Henriques 2003, 125-71.) Andor has direct links to the Jamaican music business, and he pays special attention to playing the latest tunes that have just come out. As a skilled professional, he maintained strong communicative contact with his audience through the microphone. Combining Jamaican Patois ${ }^{1}$ and Finnish, he hosted the audience into party mood by shouting, translating the messages playing in the music into Finnish,

1 Jamaican Patois is a creole language derived from English and West African languages and spoken in Jamaica and in the Jamaican diaspora. 
advertising upcoming live performances, or inviting the patrons to dance. Among the audience, there always seemed to be people present for whom the contemporary Jamaican music was familiar, though they were a small minority. The venue had a small performing stage beside the DJ booth, and typically a few clients would already start dancing with improvised moves in front of the stage during Andors' set, before the live acts. More people would normally join the dance during and after the show.

On my first night in this club, Jahvice moved to the brightly illuminated stage and started his set a bit before midnight. Andor had already got the dance floor started and moving energetically. Jahvice was dressed casually, seemingly in his everyday clothes, with his glasses, a brown jacket and a blue dress shirt. He had covered his massive dreadlocks with a cap. As he walked alone across the stage evenly and casually, I noticed that dreadlocks and a small necklace were his only bodily Rastafarian symbols. Andor worked as his backing DJ behind during the show, and soon when the music started I noticed that at Reggae Stomp, Jahvice used different backing tracks, or 'riddims' in reggae terminology, that I had heard on his single releases. These were upbeat rhythms that got people to keep dancing and a few more to approach the stage when Jahvice began his set by singing the chorus for his opening track with his gruff voice:

World is a ghetto/

It doesn't care whether you live or die/

World is a ghetto/

One less mouth to feed/

One more mother cry ${ }^{2}$

(Jahvice 2011).

My impression was that the rather sparse audience on this night was not very familiar with the performer or his lyrics. Around twenty people responded to the show by moving rhythmically in front of the stage, and the rest, including me, followed the show from a distance while chatting around the tables and sofas. Jahvice performed rapping and singing to different riddims one after another. After finishing his first song, he started a song with a chorus featuring localized spiritual themes: 'Jahjah ${ }^{3}$ is my guiding star/I take my guidance from the northern star'. Lyrically most of Jahvice's songs addressed abstract spiritual themes or social critique in dread talk.

2 I have transcribed the lyrics using the lyrical form of the released audio tracks.

3 Here Jah or Jahjah refers to the Rastafarian understanding of God. 
These themes were universal, and not particularly focused on any specific event or time. Conventional dread talk terms such as 'Babylon', 'Jah', 'herb', 'ganja', 'Selassie' and 'Zion' were all very frequent in Jahvice's lyrics. He delivered one tune after other, taking short pauses between.

To my surprise, at the end of his show Jahvice changed language and started to perform songs in Finnish. To my knowledge, these songs were unreleased, and I hadn't heard them before. In stark contrast to the earlier songs, he began a piece which dealt with drinking and partying - I keep knocking the drinks until they get to my head'. ${ }^{4}$ After this, he moved in his next song surprisingly smooth back to spiritual themes this time in Finnish with a catchy chorus: 'Jahjah is the father and I am the son'..$^{5}$ When he had finished this piece, Jahvice ended his performance, and retreated from the stage. Andor then encouraged the crowd with his microphone and asked for their applause. Once a few female dancers in front of the stage had made enough noise, Jahvice returned to the stage for an encore, this time delivering his song again in dread talk. After the encore, more people seemed to hurry on to the dance floor, as Andor commenced his next set with cheerful tunes and hyping the crowd with the microphone.

While I interviewed Jahvice before his performance, he sharply differentiated the musical code of Reggae Stomp from the sound system performances of Intergalaktik Sound. When I asked Jahvice a general question whether his Rastafarian conviction affects his music, he replied that it has deeply affected the way Intergalaktik Sound functions, but it does not bind him as a solo artist. Particularly interesting was the way he ended his response to me:

[...] I think myself also like/ that there is me as an artist and me as a rasta/ so/ [...] / I don't necessarily start to do in a sound system stuff like yeah/ today we are going to get mad drunk and stuff like that/ that kind of songs/ but then for example today I am going for example/ to reggae stomp/ where ninety per cent of the people are/ very very drunk/ so surely I will sing/ like songs like/ like yeah today we are going to get drunk/ but that is then/ the place/ where we don't aim that high/ I am not necessarily there as a rasta/ at that moment/ on the stage/ but everybody takes their own responsibility/ if somebody thinks that/ oh they don't want to hear or I have sold out/ somehow/ for me personally I don't mind/ so so/ they are different things/ you must categorize/ you must be able to understand the fact that/ people

4 'Nostan kuppii kuppiii kunnes se nousee nuppiin nuppiin'

5 'Jahjah on isä ja minä se poika.' 
are not just/ [...] / or if they are/ like that/ I can go away/ I am not interested/ if somebody wants to complain/ about these kind of things/ [...] $]^{6}$ (Jahvice 2012.)

Jahvice suggests that Reggae Stomp is in a stark contrast with the roots reggae sound systems (to which he refers here simply as 'sound system'). In his view, 'sound system' overlaps naturally with Rastafarian values, whereas Reggae Stomp as a mainstream reggae club, 'where the aim is not so high', does not; and it is the consumption of alcohol and orientation to alcohol in music, in particular, which distinguishes these spaces. Jahvice emphasizes that he, as a performer, can move between these musical subcultures and switch his musical code accordingly; only at roots reggae sound system events do his Rastafarian convictions constrain his performance. Jahvice presents himself as a particularly versatile performer, able to move dynamically between different musical subcultures. Nonetheless, he concedes that some have seen him as losing authenticity as a Rastafarian performer because of his mobility between these musical subcultures, and he seems to respond to such claims at the end of his account.

As a performance event, the Reggae Stomp gig followed the format of a live band event. In an interview with the author, Andor stated that live artists are the catch that attracts a Finnish crowd. As with the other guest artists visiting Reggae Stomp, Jahvice's performance was a clearly framed live event, functioning and advertised by Andor as the highlight of the evening. This impression was strengthened by the clearly lit separate performance stage in the otherwise darkened cafeteria, where the focus was constantly on Andor or on Jahvice. This format of a live band event could be described a part of what Mark Slobin (1993, 27-35) calls a musical superculture - a broadly shared and mediated larger unit, which affects subcultural units, and which is the most familiar mode of popular music performance for local audiences in Finland. The night still featured the classical elements of a sound system performance in Andors' set, but Jahvice's performance

6 '...Mä ajattelen itseäni myös sillee/ Et on artistiminä ja on rastaminä/ Ni/.../En mä välttämättä niinkun ala soundissa tekemään sellasta niinkun et joo/ Tänään niinkun joo nyt perseet olalle ja ryypätään ja näin pois päin/ Biisejä/ Mut sit taas niinkun esim tänään mä oon menoss esimerkiks/ Johki Reggae Stomppiin/ Mis yheksäkytprosenttii ihmisist siel on/ Kauheessa kännissä/ Ni varmasti laulan / Niinkun biisejä et/ Niinkun joo tänään dokaillaan/ Mut se on taas sitten/ Se on se/ Mis mennään/ Sieltä missä se aita on matalin/ Et mä en oo välttämättä rastana/ Juuri sinä hetkenä siellä/ Lavalla/ Mut jokanen ottaa sen oman vastuunsa/ Jos joku on sitä mieltä että/ Tää ei haluu kuulla tai sä oot myynyt/ Jotenkin tässä nyt näin/Se on taas mulle taas sit henkilökohtasesti/ Sama/ Et et/ Ne on eri juttuja/ Et ne pitää lajitella/ Pitää pystyä ymmärtämään se että/ Ihmiset ei oo vaan sellasia niinkun/.../ Tai jos ne on/Sit sillee/ Et mä kyllä voin lähtee kävelemäänkin/ Ei mua kiinnosta/ Jos joku haluaa alkaa nillittää/ Tällasista asioista/...' 
was clearly distinct from this. Jahvice was acting within the boundaries of a conventional live performance, where the audience expected him to deliver clearly framed song compositions. As I will demonstrate below, this differs starkly from the performance practices prevalent in the roots reggae shows of Intergalaktik Sound.

Jahvice seemed to use and combine two indexical orders in his performance. First, there were the typical roots reggae tunes that I had come to know him for, where he used the verbal conventions of dread talk systematically. These were also tunes that he has released through the Intergalaktik label. In our interview, Jahvice considered that these lyrics did not carry any explicit transcendental or informative significance for the majority of the audience. Thus, for Jahvice lyrics indexing to Rastafarian identity seemed to be somewhat out of place in Reggae Stomp, and he accordingly performed a creative code switch to a different indexical order, which he described in our interview as more appropriate to communicate with his audience for this club. Lyrically, this code was constructed by the use of the Finnish language and, according to his words, more mundane lyrics, which seemed to fit the audience's expectations of a live reggae vocalist's performance in this particular club. In Jahvice's description, this lyrical code acts as indexical order for a Finnish reggae culture, where themes on alcohol consumption would be normative.

The code switch between lyrical practices was accompanied by a change in sonic orientation as well. Jahvice explained in our interview that he does not use the riddims produced by the Intergalaktik Sound team when performing with a regular public address system found for example in Café Mascot. The riddims of Intergalaktik Sound are designed for more powerful public address systems, which the roots sound systems are expected to use, and in most venues these beats could not be felt. As, for example, Christopher Partridge (2010, 138-45) and Julian Henriques (2003, 65-122) have noted, Jamaican sound systems have historically aimed to construct their audio systems so that the extreme low frequencies of the riddims can be felt intensely and physically, in the abdomen. In Reggae Stomp, the backing DJ Andor had picked more upbeat riddims for Jahvice, which did not feature such deep bass sounds. Roots reggae events and specifically their soundscapes are distinguished from club events like Reggae Stomp by their emphasis on the physical and bodily effects of the bass, but Jahvice has found ways to modify his performance to fit different musical aesthetics and musical productions. 


\section{Roots Reggae's Sonic Dominance at the Voltti Club}

In November 2011, the Jamaican roots reggae singer Earl 16 was scheduled to perform at the Voltti reggae club in Tampere. Jahvice and Nestori were booked as a support act for the event, alongside local selectors and a female vocalist, Saarna. Voltti is a Tampere-based reggae club active since the early 2000s, hosted at the moment by two selectors, Rufus and Jere Dangerous, who are Finnish males in their thirties employed outside the music scene. Voltti has been held irregularly in a number of different venues over the years. The Earl 16 show was taking place in a bar called 'Tampereen Klubi', one of the main club venues in the city, as the organizers were clearly expecting a fairly big crowd for the night.

As a reggae club, Voltti is characterized by its counter-cultural orientation. The hosts, Jere Dangerous and Rufus, have a long history as selectors, and in the club they play only reggae music released in vinyl format. Jere Dangerous and Rufus are not interested in Rastafarian spirituality as such, but rather, as Jere Dangerous explained in our interview, the aesthetics related to vinyl records is a crucial matter for them. Here he answers my question why he does not seem to play contemporary Jamaican music in his sets:

[...] Yeah see I cannot anymore/ because Jamaica does not release vinyls/ and I play only 7-inch records/ all the music that I play/ in every fucking place/ every song/ is 7-inch vinyl record/ or 12-inch single/ if but/ let's say ninety six percent is 7-inch vinyl record/ and it is my/ it is more important than the rasta thing/it must be a 7-inch/it cannot be negotiated/I will never play any music with a computer $[\ldots]$ and it does not fit into to the dancehall aesthetics/ and techniques/ vinyl does not fit in there anymore/ they want that kind of/ switches measured in seconds/ and they want to chop it/ and those zag-zag noises/ they want those computer sounds/ they want it like that/ it is like/ it sounds cool yeah/ but it is a totally different thing. ${ }^{7}$ (Jere Dangerous 2012.)

\footnotetext{
7 [Jere Dangerous]: Joo kato en mä pysty enää/ Koska Jamaika ei enää julkase vinyyleit/ Ja mähän soitan pelkästään seiskatuumasii levyjä/ Kaikki musa mitä mä soitan/ Ihan joka vitun paikassa/ Jokanen biisi/ On seiskatuumanen vinyylilevy/ Tai kakstoistatuumanen single/ Jos mut/ Sanotaan yhdenksänkytkuus prosenttisesti se on seiskatuumanen vinyylilevy/ Ja se on mun semmonen/Se on tärkeempi kun rastajuttu/ Pitää olla seiskatuumanen/ Siitä ei siitä ei tingitä/ En tuu ikinä soittaan tietokoneella mitään musiikkia/ [ ...] Eikä se niinkun siihen dancehallin estetiikkaan/ ja soittotyyliin/ Ei se vinyyli niinkun enää sovi/ Enää sovi siihen/ Nehän haluu semmosia/ Sekunttien mittasia/ Biisivaihtoja/ Ja haluaa niitä pilkkoo niinkun/ Ja haluu niitä säksätysääniä/ Haluu niit tietokoneääniä/ Haluu sitä semmosta/ Mikä on niinkun/ Se on ihan siistin kuulosta/ Mutta se on oma juttunsa/.
} 
This use of vinyl records affects the performances at the club at several levels. First of all, since vinyl production sharply decreased in Jamaica at the turn of the millennium, Voltti selectors no longer follow the new releases of Jamaican music, which is fundamental for Andor and Reggae Stomp, for example. Instead they follow European and Japanese vinyl re-releases of Jamaican roots reggae from 1960 to the early 2000s, and current European roots reggae releases on vinyl. Secondly, with vinyl records, the pace of switches between the tunes is slower. This also affects the sound of the music, since the use of live samples, or what Jere Dangerous calls 'computer and zag-zag sound', is more limited in music without computer technology. Finally, this links the club to a broader cultural turn, where the vinyl record is considered as an authentic object for performance. (On contemporary vinyl cultures, see Bartmanski \& Woodward 2013.)

Marvin Sterling (2010, 143-89) suggests that roots reggae sound system aficionados in Japan embody Rastafarian lyrics and imagery to express a sociopolitical critique, and that they use this further to distinguish themselves from the majority of Japanese sound systems, which they see as commercial and apolitical. In addition, I argue that not only Rastafarian lyrics and imagery, but also a specific orientation to technology is used to distinguish roots reggae sound system events from the alleged mainstream club culture. (On distinctions in club culture, see Thornton 1995.) The claims of authenticity through vinyl also connect Voltti Klubi to broader countercultural currents. Jere Dangerous does regular gigs where he plays 1970s punk and rock music from vinyl records in punk-oriented bars and in Irish pubs. Because of his affective relationship to vinyl, Jere Dangerous considers himself to be somewhat excluded from what he sees as mainstream Finnish reggae.

When I arrived at Tampereen Klubi to see the Earl 16 performance, something unexpected had happened: A notice had been taped to the door informing us that Earl 16 had missed his flight from England, and would not be performing. The admission fee had been reduced, and the Finnish support acts would be performing normally. Inside the club, I noted that the venue's performance stage was covered with curtains, and was not going to be in use during this evening. The selectors had instead erected their equipment in front of the back wall at the other end of the hall. The whole hall was darkened and there were no heavy spotlights on the selectors. Speaker sets had been put up next to the selector's tables, and during the early evening Jere Dangerous, dressed in a neat dress-shirt and sweater jacket, was playing older 1970s and 1980s reggae tunes with a rather slow 
tempo. During the night, the selectors changed without my noticing, and they generally did not communicate with a microphone to the audience. Other selectors gathered beside the table drinking beer and chatting when they were not playing records.

First Saarna approached the selector's table and sang a few songs in dread talk standing statically behind the table. She was dressed in a decorative gothic black vest and wearing her red dreadlocks as a topknot bundle on top of her head. Nestori and Jahvice then approached the floor and the table. Here again, both of them were dressed casually in everyday clothes - dress shirts and sports jackets. Jahvice called out to the audience, inviting them closer to the floor and invoking the name of Intergalaktik Sound. Little by little the floor filled up, and I estimated that around 50 people were following the session by standing or by moving their bodies rhythmically to the music. Nestori and Jahvice positioned themselves with the microphones in front of the table and took turns in improvised order, singing Intergalaktik sound tunes to various instrumental tracks. Their bodily performances were static - both men delivered their lyrics simply by standing and waving themselves with small movements to the beat. They did not perform their tracks continuously, but took breaks and let the selectors play tracks without live vocals by Intergalaktik; but the musicians stayed around the table all the time, at times hyping the audience with shouts into the microphone, signifying (identifying) the tunes and themselves as Intergalaktik vocalists. Saarna also returned to sing with the Intergalaktik Sound vocalists - this time in Finnish. In contrast to Saarna, both Intergalaktik Sound vocalists performed all their tunes and communication in dread talk and concentrated once again on spiritual themes. The only exception to the use of Dread talk was Nestori's Finnish language reggae track 'Vuorilla on Maa' with its themes of longing-'Up on the hills there is Land/Oh when I will get there's.

The audience formed lines towards the selectors and vocalist and they responded to the steady deep bass lines by rhythmic movements. Gradually the bass lines and volume became more intense. Most of the people seemed to be dancing alone, but there were also some couples intertwined with each other. Traditional skinhead and punk styles formed a visible segment among the audience. During the singers' breaks, people remained on the floor. Here, as in Helsinki, I did not spot any Rastafarian symbols among the dancing audience, again consisting of mostly white Finnish women and few black and white men.

8 'Yhäällä vuorilla on maa/ Oi kun mä kerran sinne käydä saan' 
At this event, the vocalists were not framed as a conventional live band performance as in Reggae Stomp. Rather, Voltti club consistently followed the mode of classical sound system performance described for example by Norman Stolzoff (2000) and Julian Henriques (2003), where the DJs actively construct the recorded music into a live delivery during the course of the whole event by spontaneous shouts and lyrical performances (see also Ramstedt 2014). Despite this, at the Voltti event the focus was not on the entertainer but rather on the soundscape, which the human vocalists constructed together with the recorded music. The lack of a clearly separate performance stage and the static body language of the vocalists reinforced this impression. Jahvice commented that this type of sound system performance is often still alien to Finnish audiences, who expect a clearly framed live show. Peter Manuel and Wayne Marshall (2006) mention that these improvised live DJ performances have also become increasingly rare in sound system events in Jamaica since the mid 1980s.

Roots reggae sound systems, such as this Voltti event, are sites where Intergalaktik Sound attempts to construct, both with their music compositions and with their public address system, an environment where the sound can be physically felt as intensely as possible. These performances resonate with the Jamaican dub music tradition, with which the performers very consciously identify. Dub was first identified as a distinct music genre in the 1960s, referring to studio remixes of instrumental reggae tracks where especially the bass sounds were enhanced to the maximum (Veal 2007; Partridge 2010). Julian Henriques and Christopher Partridge have interpreted the dub tradition as connected with Afro-Caribbean religious traditions and with understandings of transcendence. In sound systems, the sonic power of the low-frequency sound over the material can be interpreted as carrying spiritual meanings. The extreme bass and other low frequency sounds also carry obvious gendered cultural meanings, as a symbol of male religious authority. (Partridge 2010, 138-45; Henriques 2003, 65-122.) Henriques (2003, 175-206) has further observed that the DJ's constant vocals over the booming bass in a darkened sound system venue can at times be likened to acousmatic sound, a sound disembodied from its source, using Michel Chions' (1999, 17-30) terminology. This seemingly omnipotent and all-seeing disembodied auditory presence is central to human experience of the supernatural. From this viewpoint, it is crucial that the role of the vocal performers in the sound system session must not be highlighted, for example with spotlights. In the same vein, Henriques compares the DJ's constant and improvised voicing to glossolalia, where religious ecstasy is 
vocalized. Many artists and organizers commented to me that these factors of sonic intensity and the shared trance of the event are one of the main factors that make roots reggae sound systems so appealing. Some Rastafarians described this specifically as a Rastafarian experience, whereas the majority considered the phenomena intensive on its own right.

The bass-heavy sound aesthetics and other features of sonic intensity observed at the Voltti club are used in other electronic dance music and black popular music genres as well. However, in the Finnish context the articulation of these dub music techniques with Rastafarian dread talk distinctively constructs Intergalaktik Sound performances as roots reggae. In the case of Reggae Stomp, we saw that the disembodied vocal presence, the extreme bass and the Rastafarian language are not given the same weight in reggae clubs that conform more closely with the supercultural modes of performance, such as with live band events or with more contemporary Jamaican dance music. Roots reggae performances thus stand out as a distinctive subcultural unit within the larger Finnish reggae scene.

\section{The 'Deep Play' of Roots Reggae}

The Intergalaktik Sound vocalists see roots reggae sound system performances as linked to the Rastafarian movement. However, at the Voltti event the audience seemed no better informed about Rastafarian spirituality than at the Reggae Stomp. Moreover, the alcohol consumption seemed to be similar at both venues, although Jahvice had named this as one of the crucial differences. When I asked Jahvice a general question on how people identifying themselves as Rastafarian have responded to his music, he ended his reply by stressing that reggae should not be considered as sacred, but that roots reggae sound systems should rather be understood as a place where a vocalist's own Rastafarian conviction or livity can be visible:

[...] When a sound is playing it is like.../ most of the biggest names/ it is very/ oriented to Rastafari/ but still/ I don't see it as SACRED/ but that it is more like/ 'everyday livity/ is rastalivity' / Why it wouldn't be visible there in the music/[...] /So in a way it just uplifts your own feelings ${ }^{9}$ (Jahvice 2012.)

9 '...Soundi soittaa niin kyllä se on niinkun/ Suurin osa tällasista isoista nimistä/ Kyll se on niinkun hyvinkin/ Tämmöstä rastasävytteistä/ Mut edelleenkään se että/ En mä nää että se on PYHÄ̈̈/Vaan se on enemmänkin sitä että/ Et everyday livity/ Is rastalivity/ Miksei se näkyis siellä musiikin puolella/.../ Et se tavallaan vaan upliftaa niitä omia fiiliksiä/...' 
Here Jahvice identifies Rastafarian beliefs as a features applying to most of the well-known roots reggae sound system operators. Despite this, the sound system event itself is not sacred, in the sense of being mandated by Rastafarian ritual code or constituting a place for explicitly experiencing Rastafarian spirituality. Rather, for both vocalists the appropriate sacred site to experience transcendence through the Rastafarian tradition was Nyabinghi - the ritual gathering of the Rastafarian community featuring ceremonial drumming and chanting. Nyabinghi sessions are generally open only to those with Rastafarian beliefs, but the Intergalaktik vocalists said that in some cases they try to capture the mood of Nyabinghi chants in their reggae vocals. Despite this, reggae and Nyabinghi are clearly received, performed and experienced quite differently. (On Nyabinghi, see Bilby 2012; cf. Reckord 1998.) Similarly, Timothy Rommen has observed that the actual spiritual practices of Rastafarian religious communities, such as Nyabinghi rituals, seem to have developed fairly independently from reggae as popular music (Rommen 2006; compare with Savihinsky 1994). As Jahvice commented, the link between roots reggae sound system performances and the Rastafarian movement exists mainly because most of the vocal artists in the roots reggae genre identify publicly as Rastafarians, and in the words of Jahvice 'promote their livity' in their lyrics.

I argue that sound system events, such as Intergalaktik Sound performances, can be understood as a central public element for Finnish Rastafarians, since Rastafarians in Finland have not generally held open functions as a religious community. In the Caribbean context, some scholars have understood sound systems as a powerful public medium where alternative histories of the black subaltern have been brought into public view, and which has produced its own distinctive modernist and diasporic musical aesthetics. (Veal 2007, 196-219, 249-257; see also Hebdige 1979, 30-45.) In the contemporary Finnish context, reggae performances seem to offer a similar subcultural and utopian space for the vocalists to embody religious Rastafarian identity in the public space. A religious identification already makes the vocalists subcultural in the Finnish context, since in Finnish society the public sphere is generally marked by a high privatization of religion (Kääriäinen et al. 2003). The use of dread talk distances the Rastafarian identity from the Finnish locality, and makes this enactment of religious identity more sustainable.

For the Intergalaktik Sound vocalists, dread talk was the main means to embody Rastafarian identity in performance. Lyrics about alcohol consumption were problematical to fit into this indexical order of Rastafarian spiritual 
terminology, since alcohol has generally been a taboo in Rastafarian livity in Jamaica, where the language first originated (Homiak 1995). However, the consumption of beverages did not seem to be any way limited or socially stigmatized in the Voltti club; in fact Jahvice saw reggae lyrics about alcohol as an integral part of the lyrics of Finnish language reggae music. Generally, these Finnish reggae lyrics were not blended with Rastafarian dread talk, but the two indexical orders were kept separate. This indicates that it is easier to adapt the musical structure of bass-heavy dub to local club culture practices than to translate the meanings of its lyrics in Rastafarian language into Finnish (See also Rommen 2006; cf. Pollard 2000, 96-108). As we saw above, performers often use both Finnish lyrics and dread talk lyrics in the same sessions, but the Rastafarian subject position is not present in the Finnish lyrics, although spiritual topics of a more general nature might be addressed in Finnish.

Rastafarian language seems to be a crucial intercultural factor in connecting Intergalaktik Sound to the wider European roots reggae culture. The group has collaborated with other European groups, performing for example with the likes of Earl 16, and recording together with foreign guest vocalists. Most of their vinyl releases are also sold abroad in Europe. Roots reggae in Finland is constructed as part of this transnational network. This further explains why, contrary to the expectations of Velma Pollard (2000, 96-106), dread talk is not generally blended with Finnish lyrics, but is used as a consistent distinct lexical order. Interestingly, the decline of vinyl and sound system culture in Jamaica means that the Caribbean no longer functions as a cultural center for this European roots reggae sound system culture, but rather this network follows the new vinyl releases of the most influential British roots reggae sound systems. ${ }^{10}$

Rastafarian lyrics were used also in the more supercultural environment of the Reggae Stomp club, but without the bass-oriented sound system technology and its dub sound. Consequently, Jahvice did not consider Reggae Stomp as a roots reggae event. The sonic intensity of dub defines roots reggae sound systems and characterizes them as sites with special affective significance for Nestori and Jahvice. Deep bass sounds and vinyl records were seen as a further key linking Finnish roots reggae sound systems with other contemporary roots reggae sound systems and with the reggae tradition which the informants considered lost in the Caribbean. Vinyl culture

10 Jah Shaka Sound System, Aba Shanti-I and Iration Steppas were some of the sound system mentioned by the informants as central to European roots reggae. On the development and history of British roots reggae sound systems, see Partridge 2010, 98-145; Veal 2007, 227-35. 
is not by any means unique to roots reggae; it has been present in other electronic music scenes in Europe for decades. Bartmanski and Woodward (2013) call the aesthetics of vinyl and the ritual listening to records 'deep play' - a form of counter-reaction to the fast digitalization of music formats and to the individualization of listening practises. In fact, the collecting of vinyl records has held a specific significance in the history of Finnish reggae ever since the 1970s, because of the lack of a live reggae scene until the 1990s. This might partly explain why vinyl is so strongly considered a key object in identification for the reggae tradition in Finland. The construction of a tradition and culture of ritual listening through the vinyl medium is an aspect through which Finnish roots reggae sound systems can be considered as part of what Christopher Partridge (2004) has called the re-enchantment of the west. One can see sound systems as seeking to re-enchant musical experience in a period when music technology in general is focused on creating individually controllable and immaterial - or in Weberian terms disenchanted - sound experiences.

Roots reggae performances form what Jan Blommaert (2010) has called a polycentric site where different, but at the same interlinked, discursive elements are articulated together. These events articulate the vocal enactment of Rastafarian identity together with a musical 'deep play' culture. In the Finnish context, where the references to the black liberation struggle are culturally distant, this articulation can give meaningful content to the rather abstract Rastafarian concept of 'naturalness'. In the context of roots reggae, the Rastafarian 'natural' way of life resonates with the communicative musical ritual of sound systems, which entails a sense of continuity with the Jamaican tradition and a corporeal sonic experience - a livity which 'uplifts your feelings', in the words of Jahvice. It important to note that even if many of the Rastafarians in Finland are involved in roots reggae, this articulation is only one side, although the most public one, of Rastafarian livity in Finland. As Tuomas Äystö (2012) has documented, Finnish Rastafarians can hold a number of more private ways of expressing their identity. In addition, we saw how Rastafarian vocalists are not bound to this identification, but they can move and switch between different super- and subcultural musical practices. Similarly, many roots reggae aficionados, such as Jere Dangerous, do not identify themselves as Rastafarians and do not articulate the subcultural aesthetics of roots reggae in relation to the Rastafarian movement, but to their own secular identifications. Roots reggae sound systems can therefore provide shared aesthetic experiences without shared religious identifications, and the events can be experienced 
and articulated simultaneously as both religious and secular by different individuals in the same space (Cheetham 2010). Blommaert argues that this heterogeneity is a feature of superdiverse globalization: a number of indexical orders, with different histories and centers, can manifest themselves in the course of one event and from the same practises and cultural objects, such as vinyl records. (Blommaert 2010, 28-32.)

This study has demonstrated how two Finnish roots reggae vocalists identify themselves as Rastafarians by using mostly the classical dread talk lexicon as described by Velma Pollard (2000) in her seminal work. Dread talk is filled with religious motifs and used in both super- and subcultural musical venues. Despite this mobility, I further argued that the roots reggae sound systems are the main public medium for expressing the Rastafarian livity in Finland. Roots reggae performances are constructed by articulating the musical aesthetics of dub together with dread talk lyrics. The Intergalaktik vocal artists and Voltti selectors considered this form of sound system as an enchanted space. This enchantment of roots reggae performances depends further on the incorporation of vinyl records as auratic objects. Following the work of Bartmanski and Woodward (2013), I have used the term 'deep play' to describe this type of music listening and performing. The research participants contrasted 'deep play' as distinct both from digitalized Jamaican music and from local reggae in Finnish, which hold more supercultural positions. At the same time, the Rastafarian vocalists were very well versed in these music supercultures and participated in them; perhaps this makes the difference between roots reggae and the alleged mainstream more relevant for them. Finally, I suggest that in the Finnish context this form of 'deep play' resonates with Rastafarian notion of 'natural' life or livity. 
Bibliography

Audio tracks

Jahvice

2011 World Is a Ghetto. Intergalaktik Sound. IGS007.<http://www.youtube. com/watch?v=qVq903nRWv8>, accessed 27.6.2014.

\section{IGS Posse}

2012 Northern Star. <https://soundcloud.com/jahvice/igs-posse-northernstar>, accessed 27.6.2014.

Interviews

Andor

2012 Duration 84 minutes, 30.7.2012 Helsinki, in the possession of the author.

Jahvice

2012 Duration 79 minutes, 12.7.2012 Helsinki, in the possession of the author.

\section{Jere Dangerous}

2012 Duration 63 minutes, 12.5.2012 Tampere, in the possession of the author.

Nestori

2012 Duration 103 minutes, 21.8.2012 Helsinki, in the possession of the author.

Field diaries

Field diary 2011. 25.11.2011. In the possession of the author.

Field diary 2012. 11.7.2012-24.8.2012. In the possession of the author.

\section{Literature}

Blommaert, Jan

2010 The Sociolinguistics of Globalization. Cambridge: Cambridge University Press.

Bilby, Kenneth \& Elliot Leib

2012 Kumina, the Howellite Church and the Emergence of Rastafarian 
Traditional Music in Jamaica. - Michael Barnett (ed.), Rastafari in the New Millenium, 255-69. Syracuse, NY: Syracuse University Press.

\section{Bartmanski, Dominik \& Ian Woodward}

2013 The Vinyl: The Analogue Medium in the Age of Digital Reproduction. - Journal of Consumer Culture 0 (0), 1-25. <http://joc.sagepub.com/ content/early/2014/07/13/1469540513488403>.

\section{Cashmore, Ernest}

1982 [1979] Rastaman. The Rastafarian Movement in England. London: George Allen \& Unwin.

\section{Cheetham, David}

2010 Exploring the aesthetic 'space' for inter-religious dialogue. - Exchange: Journal of Missiological and Ecumenical Research 39 (1), 71-86.

\section{Chevannes, Barry}

1994 Rastafari: Roots and Ideology. Syracuse, NY: Syracuse University Press.

\section{Chion, Michel}

1999 The Voice in Cinema. New York, NY: Columbia University Press.

\section{Gilroy, Paul}

1995 There ain't no Black in the Union Jack: The Cultural Politics of Race and Nation. London: Routledge.

\section{Hebdige, Dick}

1979 Subculture: The Meaning of Style. London: Routledge.

\section{Henriques, Julian}

2003 Sonic Bodies. Reggae Sound systems, Performance Techniques and Ways of Knowing. New York, NY: Continuum.

\section{Homiak, John}

1995 Dub History: Soundings on Rastafari Livity and Language. - Barry Chevannes (ed.), Rastafari and Other African-Caribbean Worldviews, 127-81. New Brunswick, NJ: Rutgers University Press.

\section{Kääriäinen, Kimmo \& Kati Niemelä \& Kimmo Ketola}

2003 Moderni kirkkokansa: suomalainen uskonnollisuus uudella vuosituhannella. Tampere: Kirkon tutkimuskeskus.

\section{Manuel, Peter \& Wayne Marshall}

2006 The Riddim Method: Aesthetics, Practice, and Ownership in Jamaican Dancehall. - Popular Music 25 (3), 447-70.

\section{Lynch, Gordon}

2006 The Role of Popular Music in the Construction of Alternative Spiritual Identities and Ideologies. - Journal for the Scientific Study of Religion Vol. 45 No. 4, 481-88, 


\section{Partridge, Christopher}

2004 Re-enchantment of the West (vol1): Alternative Spiritualities, Sacralization, Popular Culture and Occulture. London: Continuum.

2010 Dub in Babylon: Understanding the Evolution and Significance of Dub Reggae in Jamaica and Britain from King Tubby to Post-punk. London: Equinox.

\section{Pollard, Velma}

2000 Dread Talk. The Language of Rastafari. Montréal, QC, and Kingston, ON: McGill-Queens University Press.

\section{Ramstedt, Kim}

2014 Sound System Performances and the Localization of Dancehall in Finland. - Iasmp@Journal, Journal of the International Association for the Study of Popular Music 4 (1), 42-55. <http://www.iaspmjournal.net/ index.php/IASPM_Journal/article/view/656>.

\section{Reckord, Verena}

1998 From Burra Drums to Reggae Riddims: The Evolution of Rasta Music. - Nathaniel Samuel Murrel (ed.), Chanting Down Babylon: The Rastafari Reader, 231-52. Philadelphia: Temple University Press.

\section{Rommen, Timothy}

2006 Protestant Vibrations? Reggae, Rastafari and Conscious Evangelicals. - Popular Music 25 (2), 235-63.

\section{Savishinsky, Neil}

1994 Transnational popular culture and the global spread of the Jamaican Rastafarian movement. - New West Indian Guide/Nieuwe West-Indische Gids 68 (3 \& 4), 259-81.

\section{Slack, Jennifer}

1996 The Theory and Method of Articulation in Cultural Studies. - David Morley \& Kuan-Hsing Chen et al. (eds), Stuart Hall. Critical Dialogues in Cultural Studies, 112-27. London: Routledge.

\section{Slobin, Mark}

1993 Subcultural Sounds: Micromusics of the West. Hanover, NH: Wesleyan University Press / University Press of NewEngland.

\section{Straw, Will}

1991 Systems of Articulation, Logics of Change: Communities and Scenes in Popular music. - Cultural Studies 5 (3), 361-75.

\section{Sterling, Marvin}

2010 Babylon East: Performing Dancehall, Roots Reggae, and Rastafari in Japan. Durham, NC: Duke University Press. 


\section{Stolzoff, Norman}

2000 Wake the Town and Tell the People. Dancehall Culture in Jamaica. Durham, NC and London: Duke University Press.

\section{Thronton, Sarah}

1995 Club Cultures: Music, Media and Subcultural Capital. Cambridge: Polity Press.

\section{Van Dijk, Frank Jan}

1998 Chanting down Babylon Outernational: The rise of Rastafari in Europe, the Caribbean, and the Pacific. - Nathaniel Samuel Murrel (ed.), Chanting down Babylon the Rastafari Reader, 199-216. Philadelphia: Temple University Press.

\section{Veal, Michael}

2007 Dub: Soundscapes and Shattered Songs in Jamaican Reggae. Middeltown, CN: Wesleyan University Press.

\section{Äystö, Tuomas}

2012 Suomalaisuus ja uskonto rastafarien identiteettikerronnassa. Unpublished Master's thesis. University of Turku. School of History, Culture and Arts Studies. Turku: University of Turku. 
